\title{
An Evaluation of Some Japanese Lisianthus (Eustoma grandiflorum) Varieties Grown in Bangladesh
}

\author{
A. F. M. Jamal Uddin*, M. S. Islam, H. Mehraj, M. Z. K. Roni and S. Shahrin \\ Department of Horticulture, Sher-e-Bangla Agricultural University, Dhaka-1207, Bangladesh \\ *Corresponding author and Email: jamal4@yahoo.com
}

Received: 8 October $2012 \quad$ Accepted: 18 May 2013

\begin{abstract}
A pot experiment was conducted for the first time in Bangladesh, at the Horticulture Farm of Sher-eBangla Agricultural University, Dhaka during November, 2010 to July, 2011 to asses the adaptability of seven lisianthus (Eustoma grandiflorum) cultivars namely Micky Rose, Pink Rose, Azuma No Yosooi, Purple Edge Glass, Piccolo Blue, Mellow Purple and Royal Violet for commercial cultivation in Bangladesh. The experiment was conducted in a Randomized Complete Block Design with nine replications. Significant differences among cultivars were noted for all the attributes evaluated. The highest number of flowers (16.0/plant) was produced by Piccolo Blue and the lowest from Pink Rose (7.0/plant). All the cultivars in this study showed very good shelf life (12.0-25.0days) in normal condition. All the seven lisianthus cultivars performed satisfactorily as ideal cut flowers. Further work may be done to develop these as commercial cultivars in Bangladesh.
\end{abstract}

Keywords: Eustoma, petal color, cut flower

\section{Introduction}

Lisianthus (Eustoma grandiflorum Grise) belongs to the family Gentianaceae. It originated from the eastern slope of Rocky Mountains (USA), where it is known as the prairies gentian (Halevy and Kofranek, 1984). Eustoma is named after the two Greek words Eu (beautiful, good, well), and stoma (mouth). Lisianthus is popular and has a number of cultivars grown for the cutflower market. Cut flower production of lisianthus has risen enormously in the recent years, and commercial cultivars have been intensively developed in Japan (Halevy and Kofranek, 1984).

Lisianthus are herbaceous annual, growing upto 15-60 cm, with slightly succulent bluish green leaves and large funnel-shaped flowers growing on long straight stems. Lisianthus are longlasting flowers with four wide ruffled and delicate petals of oval shape and various colors. Modern cultivars offer a wide range of colors including purple, rose, pink, white, and a variety of bicolor. The petals of single flowers are large and rounded with only a fuse at the base. The petals form a trumpet or funnel-shaped corolla, and are often yellow inside close to the mouth of the flowers. Some varieties have semi-double or double petals which give the impression of being roses. Growth and quality of lisianthus are variety specific and they grow well at $\mathrm{pH} 6.3$ to 6.7 (Harbaugh and Woltz, 1991). Ideal temperature range is 15 to $25^{\circ} \mathrm{C}$, though it can withstand with higher temperature. Plants show rosetting if temperature goes too high during seedling upto the 3 pair of leaf stage (Harbaugh et al., 1992). To maintain plant quality during 
high temperature and under strong light, plants require heavy watering (Brian and Katz, 1997).

Lisianthus is a newcomer in Bangladesh, which has the advantage of striking bloom with great appeal. While many new flower crops struggle to gain consumers awareness and acceptance, this has not been the case with lisianthus. Within the past 10 years, lisianthus have been the fastest growing segment of new flower category worldwide. It has a great cosmopolitan demand mainly for its large and attractive flowers, long and hard stem, wide range of colors and long vase life: the common traits of an ideal cut flower. In Bangladesh, Lisiathus is still unknown as a promising and improved ornamental plant although it might be suitable for commercial cultivation. Considering the prospect, the present research work was undertaken with seven Japanese lisianthus cultivars to find out their suitability on the basis of different parameters for commercial cultivation and to develop them as cut flower in Bangladesh.

\section{Materials and Methods}

A pot experiment was conducted at the Horticulture Farm of Sher-e-Bangla Agricultural University, Dhaka, Bangladesh during November, 2010 to July, 2011. In the experiment seven Japanese cultivars of lisianthus were used which are Micky Rose, Pink Rose, Azuma No Yosooi, Purple Edge Glass, Piccolo Blue, Mellow Purple and Royal Violet. The experiment was carried out in a Randomized Complete Block Design (RCBD) with nine replications. Seeds were collected from Sakata Seed Corporation, Japan and were sown in mid November, 2010 in soil of germination trays. Mist irrigation was provided 5-7 times a day and the trays were placed in a cool and shady place.

Following germination, 90 days old seedlings were transplanted in previously prepared pots on February, 2011 at 4 leaf stage, placed in a shade house and irrigated as required. Sixty three pots with single plant in each pot were used in the experiment. Pot mixture was prepared by mixing well decomposed cowdung, soil and sand at a proportion of 1:1:1. Data on plant height, days required to flower bud initiation and blooming, number of flower buds and flowers per plant, days to flower senescence, coloration $\left(\mathrm{L}^{*}, \mathrm{a}^{*}\right.$, $b^{*}, C^{*}, h_{a b}$ and visual color) and vase life were recorded. Petal colors at three different locations of the outer epidermis $(\varnothing 10 \mathrm{~mm})$ were measured using a handy tristimulus colorimeter, NR-3000 (NIPPON Denshoku), followed by $\mathrm{L}^{*}$ (lightness), a*, and $\mathrm{b}^{*}$ (two Cartesian coordinates), based on CIElab scale with the standard CIE observer $\left(10^{\circ}\right.$ visual field $)$ and CIE standard illuminant $\mathrm{D}_{65}$ (CIE, 1986; McGuire, 1992). Beams effective axes were at the angle of $45 \pm 2^{0}$ from the normal of the specimen surface in illuminated petals. Metric chroma, $\mathrm{C}^{*}$ and hue angel, $h_{a b}$ (CIElab notation), were calculated as; $\mathrm{C}^{*}=\left(\mathrm{a}^{*^{2}}+\mathrm{b}^{*^{2}}\right)^{0.5}$ and $\mathrm{h}_{\mathrm{ab}}=\operatorname{tang}^{-1}\left(\mathrm{~b} * / \mathrm{a}^{*}\right)$ (Gonnet, 1998).

Three stems were selected at random from each cultivar, cut to $25 \mathrm{~cm}$, and placed in a $500 \mathrm{ml}$ conical flask containing tap water. Stems that had one flower about to bloom and one or two unopened flower-bud were selected. Stem ends were cut and tap water was changed in every alternate days. The number of days till the wilting of flowers and buds were recorded to determine the vase life.

Collected data were analyzed using the MSTATC program. the means for all the treatments were calculated and the analysis of variance was performed by F-test (Variance Ratio). Differences among treatments were evaluated by Duncan's Multiple Range (DMRT) test (Gomez and Gomez, 1984).

\section{Results and Discussion}

\subsection{Plant height}

The plant height of lisianthus cultivars showed significant differences among Micky Rrose, Pink Rose, Azuma No Yosooi, Purple Edge Glass, Piccolo Blue, Mellow Purple and Royal Violet at 40, 50, 60, 70, 80 and 90 Days after transplanting. The tallest plants $(46.0 \mathrm{~cm})$ were 
produced from Pink Rose and Mellow Purple and the shortest $(39.0 \mathrm{~cm})$ was obtained from Piccolo Blue at 90 DAT (Figure 1). The result indicated that the height of different lisianthus cultivars is genetically controlled.

\subsection{Days to flower bud initiation}

Days required to flower bud initiation varied significantly among the cultivars. Flower bud initiation in Royal Violet required the longest period (117.0 days) and the shortest period (99.0) was needed for both Mellow Purple and Azuma No Yosooi (Table 1).

\subsection{Days to flower bloom}

Significant variation was found among cultivars for days to bloom (from flower bud initiation). The minimum number of days (16.0 days) required to bloom was in Azuma No Yosooi and the maximum days (22.0) required to bloom was for Micky Rose cultivar (Table 1).

\subsection{Number of flower buds per plant}

The number of flower buds per plant varied significantly among different cultivars. It was the highest (18.0/plant) in Piccolo blue, while Pink Rose carried the lowest number of 10.0/plant (Table 1).

\subsection{Number of flowers per plant}

The number of flower per plant varied significantly among the cultivars. The highest number of flowers were 16.0/plant produced in Piccolo blue but the lowest of 7.0 per plant was in Pink Rose (Table 1).

\subsection{Days to flower senescence}

Significant variation was found among the cultivars for days to flower senescence (from blooming) due to cultivars. The maximum days (32.0) were required for Piccolo Blue, while the minimum was required (21.0 days) in Azuma No Yosooi (Table 1).

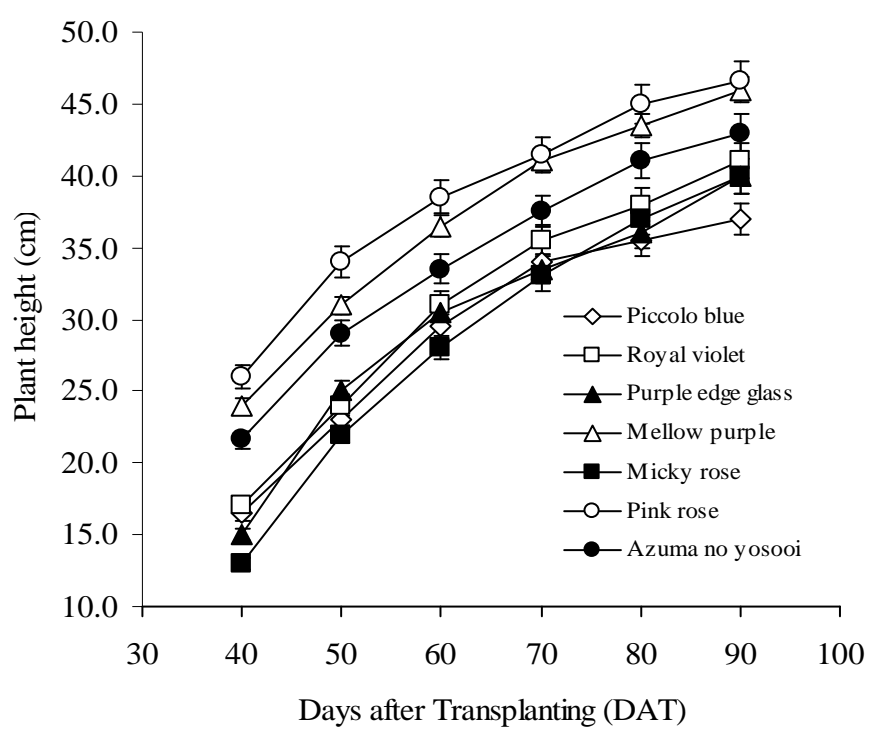

Fig. 1. Effect of lisianthus cultivars on plant height at different at DAT 
Table 1. Growth and development of different lisianthus cultivars

\begin{tabular}{|c|c|c|c|c|c|c|c|c|}
\hline $\begin{array}{l}\text { Treatment/ } \\
\text { Cultivar }\end{array}$ & $\begin{array}{l}\text { Plant } \\
\text { height at } \\
\text { maturity } \\
(\mathrm{cm})\end{array}$ & $\begin{array}{l}\text { Days t } \\
\text { flower } \\
\text { initiati }\end{array}$ & bud & $\begin{array}{l}\text { Days to } \\
\text { bloom }\end{array}$ & $\begin{array}{l}\text { Number } \\
\text { of flower } \\
\text { buds/plant }\end{array}$ & $\begin{array}{l}\text { Numl } \\
\text { flowe }\end{array}$ & $\begin{array}{l}\text { er of } \\
\text { ss/plant }\end{array}$ & $\begin{array}{l}\text { Days to } \\
\text { flower } \\
\text { senescenc }\end{array}$ \\
\hline Piccolo Blue & $39.0 \mathrm{~d}$ & 108.0 & $\mathrm{~b}$ & $18.0 \mathrm{~d}$ & $18.0 \quad \mathrm{a}$ & 16.0 & $\mathrm{a}$ & 32.0 \\
\hline Royal Violet & $41.0 \mathrm{c}$ & 117.0 & $\mathrm{a}$ & $19.0 \mathrm{~cd}$ & $14.0 \mathrm{c}$ & 13.0 & $\mathrm{c}$ & 27.0 \\
\hline $\begin{array}{l}\text { Purple Edge } \\
\text { Glass }\end{array}$ & $40.0 \mathrm{~cd}$ & 106.0 & $\mathrm{c}$ & $21.0 \quad a b$ & $12.0 \mathrm{~d}$ & 12.0 & $\mathrm{~cd}$ & 28.0 \\
\hline $\begin{array}{l}\text { Mellow } \\
\text { Purple }\end{array}$ & $46.0 \quad \mathrm{a}$ & 99.0 & $\mathrm{e}$ & $20.0 \quad b c$ & $16.0 \mathrm{~b}$ & 14.0 & $\mathrm{~b}$ & 25.0 \\
\hline Micky Rose & $40.0 \mathrm{~cd}$ & 104.0 & d & $22.0 \quad \mathrm{a}$ & $16.0 \mathrm{~b}$ & 12.0 & $\mathrm{~cd}$ & 30.0 \\
\hline Pink Rose & $46.0 \quad \mathrm{a}$ & 106.0 & $\mathrm{c}$ & $20.0 \quad b c$ & $10.0 \mathrm{e}$ & 7.0 & e & 23.0 \\
\hline $\begin{array}{l}\text { Azuma No } \\
\text { Yosooi }\end{array}$ & $43.0 \quad \mathrm{~b}$ & 99.0 & $\mathrm{e}$ & $16.0 \mathrm{e}$ & $12.0 \mathrm{~d}$ & 11.0 & $\mathrm{~d}$ & 21.0 \\
\hline $\mathrm{CV}(\%)$ & 0.6 & 2.1 & & 1.6 & 3.0 & 3.2 & & 1.4 \\
\hline LSD 0.05 & 1.7 & 2.0 & & 1.6 & 1.9 & 1.4 & & 2.0 \\
\hline
\end{tabular}

Table 2. Colorimetric characteristics and vase life of seven lisianthus cultivars

\begin{tabular}{|c|c|c|c|c|c|c|c|c|c|c|c|c|}
\hline $\begin{array}{c}\text { Treatments/ } \\
\text { cultivars }\end{array}$ & $\mathrm{L}^{*}$ & & $a^{*}$ & & $b^{*}$ & & $C^{*}$ & & $\mathrm{~h}_{\mathrm{ab}}$ & & Vase life (da) & \\
\hline Piccolo Blue & 82.0 & $\mathrm{~b}$ & 59.0 & $\mathrm{a}$ & 18.0 & $\mathrm{a}$ & 59.0 & $\mathrm{a}$ & 360.0 & $\mathrm{a}$ & 18.0 & $\mathrm{~d}$ \\
\hline Royal Violet & 86.0 & $\mathrm{a}$ & 39.0 & d & 14.0 & $\mathrm{a}$ & 39.0 & $\mathrm{c}$ & 360.0 & $\mathrm{a}$ & 14.0 & $\mathrm{e}$ \\
\hline $\begin{array}{l}\text { Purple Edge } \\
\text { Glass }\end{array}$ & 82.0 & $\mathrm{~b}$ & 49.0 & $\mathrm{~b}$ & 20.0 & $\mathrm{a}$ & 49.0 & $\mathrm{~b}$ & 360.0 & $\mathrm{a}$ & 20.0 & $\mathrm{c}$ \\
\hline Mellow Purple & 61.0 & $\mathrm{c}$ & 25.0 & $\mathrm{f}$ & 18.0 & $\mathrm{~b}$ & 35.3 & $\mathrm{~d}$ & 315.0 & $\mathrm{~d}$ & 18.0 & $\mathrm{~d}$ \\
\hline Micky Rose & 32.0 & $\mathrm{e}$ & 46.0 & $\mathrm{c}$ & 25.0 & d & 57.8 & $\mathrm{a}$ & 322.7 & $\mathrm{~b}$ & 25.0 & $\mathrm{a}$ \\
\hline Pink Rose & 61.0 & $\mathrm{c}$ & 25.0 & $\mathrm{f}$ & 23.0 & $\mathrm{~b}$ & 35.3 & d & 315.0 & $\mathrm{~d}$ & 23.0 & $\mathrm{~b}$ \\
\hline $\begin{array}{l}\text { Azuma No } \\
\text { Yosooi }\end{array}$ & 40.0 & $\mathrm{~d}$ & 29.0 & $\mathrm{e}$ & 12.0 & $\mathrm{c}$ & 39.6 & $\mathrm{c}$ & 317.0 & $\mathrm{c}$ & 12.0 & $\mathrm{f}$ \\
\hline $\mathrm{CV}(\%)$ & 2.3 & & 1.8 & & 1.7 & & 0.9 & & 3.0 & & 1.7 & \\
\hline LSD 0.05 & 3.6 & & 2.7 & & 1.4 & & 3.4 & & 1.8 & & 1.4 & \\
\hline
\end{tabular}

In a column the means having similar letter(s) are statistically insignificant while those having dissimilar letter(s) differ significantly at the 0.05 level of probability 


\subsection{Vase life}

Significant variation of vase life of cut flower was recorded among different cultivars. The maximum vase life (25.0 days) was found in Micky Rose and the minimum (12.0 days) was obtained from Azuma No Yosooi (Table 2). The vase life of lisianthus was 12-25 days which is more than those of rose, tuberose, gladiolus etc. (7-15 days) which is an indication of ideal cut flower.

\subsection{Petal color}

Significant variation was recorded among cultivars in terms of petal color. The highest (360.0) hue angel $\left(\mathrm{h}_{\mathrm{ab}}\right)$ was recorded from Piccolo Blue, Royal Violet and Purple Edge Glass and the lowest (315.0) hue angel $\left(\mathrm{h}_{\mathrm{ab}}\right)$ was noted from Mellow Purple and Pink Rose. The highest (86.0) L* was recorded from Royal Violet but the lowest (32.0) L* was obtained from Micky Rose. The maximum (59.0) a* was recorded from Piccolo Blue while the lowest (32.0) $\mathrm{a}^{*}$ in Mellow Purple and Pink Rose. The $\mathrm{b}^{*}$ was maximum (0.0) in Piccolo Blue, Royal violet and Purple Edge Glass but the least (-35.0) $\mathrm{b}^{*}$ in Micky Rose. The highest (59.0) c* was recorded from Piccolo Blue and the lowest (35.3) $\mathrm{c}^{*}$ was obtained from Mellow Purple and Pink Rose (Table 2). Findings expressed that the lisianthus cultivars showed a wide range of color. The major anthocyanidins, control the color variation of lisianthus petals and their cumulative quantities by extending chromas to individual color direction (Uddin et al., 2002)

\section{Conclusions}

Significant differences among the seven of lisianthus cultivars were found in respect of all of the attributes evaluated. In the present study all the seven cultivars performed well as ideal cut flower and therefore, could be popularized as commercial cultivars of lisianthus in Bangladesh. However, further verification regarding various factor as well as cultural practices might be needed for confirmation.

\section{References}

Brian, C. and Katz, P. 1997. A grower's guide to lisianthus production. Floraculture inter. 7: 16-19.

CIE. 1986. Recommendations on uniform color spaces, color difference evaluations and psychometric color terms. CIE central Bureau, Colorimetry, $2^{\text {nd }}$ ed. Commission International de I Eclairage, central Bureau, Viena, Austria. pp:1-83.

Gomez, K. A. and Gomez, A. A. 1984. Statistical Procedure for Agricultural Research. John Willey and Sons Ltd. New York. pp. 28-192.

Gonnet, J. F. 1998. Color effects of copigmentation of anthocyanins revisited-1. A colorimetric definition using the CIElab scale. Food Chemistry. 63: 409-415.

Halevy, A. H. and Kofranek, A. M. 1984. Evaluation of lisianthus as a new crop. Hort. Science 19: 845-847.

Harbaugh, B. K. and Woltz S. S. 1991. Eustoma quality adversely affected by low $\mathrm{pH}$ of root medium. Hort. Science 26: 12791280.

Harbaugh, B. K., Roh, M. S., Lawson, R.H. and Pemberton, B. 1992. Rosetting of lisianthus cultivars exposed to high temperatures. Hort. Science. 27: 885-887.

McGuire, R. C. 1992. Reporting of objective color measurement. Hort. Science 27: 1254-1255.

Uddin, A. F. M. J., Hashimoto, F., Nishimoto, S., Shimizu, K. and Sakata, Y. 2002. Flower growth, coloration and petal pigmentation in four lisianthus cultivars. J. Jpn. Soc. Hortic. Sci. 71, 40-47. 